International Journal of Social Sciences and Humanities
Available online at www.sciencescholar.us
Vol. 5 No. 3, December 2021, pages: $223-231$
e-ISSN: 2550-7001, p-ISSN: 2550-701X
https://doi.org/10.53730/ijssh.v5n3.2027

\title{
Applied Neuroscience in Early Childhood and High School Education
}

\author{
(D) CrossMark \\ Jacqueline Aracely Arteaga Guerrero a, José Atilio Murillo Moreira ${ }^{\mathrm{b}}$, María José Zambrano \\ Zambrano $^{c}$, Fernando Eduardo Cornejo Rivas ${ }^{d}$, Marilyn Lidia Basurto Pilligua ${ }^{e}$
}

Manuscript submitted: 09 September 2021, Manuscript revised: 18 October 2021, Accepted for publication: 27 November 2021

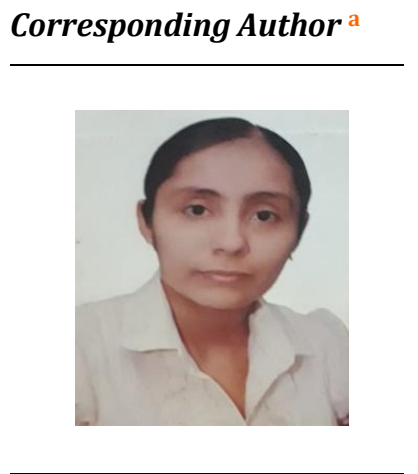

Keywords

memory; metacognition;

neurons;

stimulus;

training;

\section{Abstract}

Neuroeducation is a very complex practice that has allowed us to know how the human brain acts from its plasticity and wide synaptic connectivity, one of its important characteristics is that it acts cognitively and emotionally, strengthening the teaching-learning process from an early age. An analysis is made of the ideas that various authors have had in the application of neurosciences in the educational field. The objective of this work was to identify, through the interpretation of data, what was the contribution of neurosciences in children in initial and preparatory education of the Mathius Quintanilla Sierra Educational Unit, in the city of Portoviejo, as well as the methods, techniques, and strategies used by teachers for the construction of knowledge. The methodology used was non-experimental, descriptive, and explanatory, from which it was possible to analyze and understand the information raised by various authors from their professional and personal perspectives. As a result, it was obtained that teachers at these levels do not have a perfect knowledge of neuroeducation; However, they are aware that the brain at an early age learns very easily to that of an adult, considering that stimulation and orientation are necessary, as well as adequate nutrition from initial education, to develop its various brain functions and identify skills, talents, and skills that are part of the wide range of multiple intelligences.

International Journal of Social Sciences and Humanities (C) 2021.

This is an open access article under the CC BY-NC-ND license (https://creativecommons.org/licenses/by-nc-nd/4.0/).

\footnotetext{
a Pontificia Universidad Católica del Ecuador, Manabí, Portoviejo, Ecuador

${ }^{\text {b }}$ Pontificia Universidad Católica del Ecuador, Manabí, Portoviejo, Ecuador

c Pontificia Universidad Católica del Ecuador, Manabí, Portoviejo, Ecuador

${ }^{d}$ Pontificia Universidad Católica del Ecuador, Manabí, Portoviejo, Ecuador

e Pontificia Universidad Católica del Ecuador, Manabí, Portoviejo, Ecuador
} 


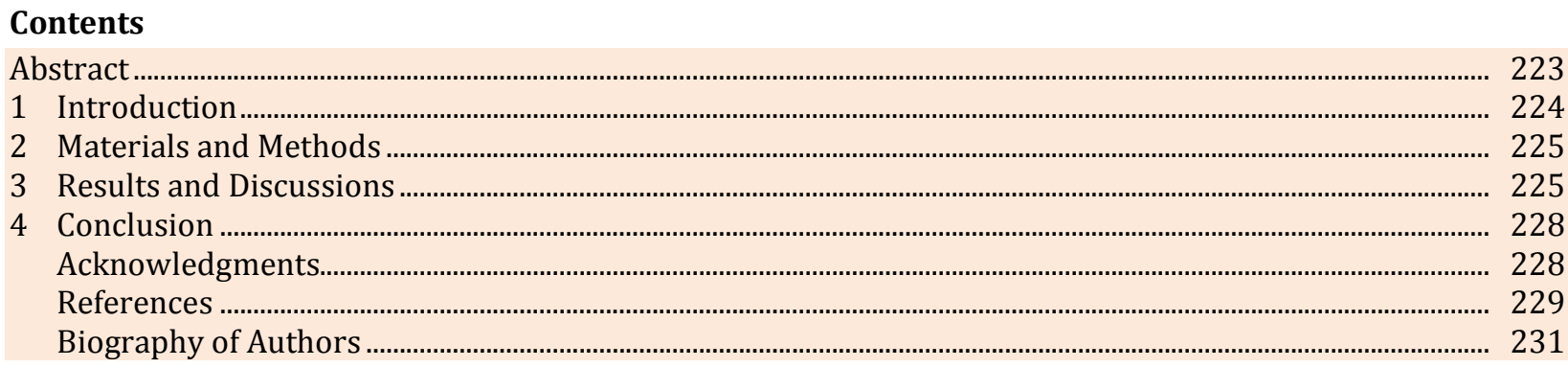

\section{Introduction}

Human beings have always been the object of research, achieving multiple indispensable results in the field of science, especially in education; These have enriched the world of knowledge, clearing up existing doubts about the study of the brain, which for years has been revolutionizing knowledge responding to how and why, improving its performance in various areas of life, are related to memory, motivation, attention, sleep and a healthy diet, all this occurs in a combination of the multiple ways of learning, both in the human intelligence of each one and in school (Dehaene, 2019).

Neuroscience is born from the exploration of the thinking organ of the human being and the first indications occurred in prehistory, a time in which it is suspected that very old surgical techniques called trepanations were practiced. The bones found allowed us to establish an indication of neuroscience, its first stages range from classical antiquity and medieval times to the Renaissance, then, the question arose as to what was the origin of sensory, motor, and mental functions so that What today is very common to interpret, in its times was a subject of much discussion (Palacios, 2021).

In the $60 \mathrm{~s}$ of the 20th centuries, neuroscience emerged as an interdisciplinary study, this discipline has made leaps and bounds thanks to technological advances; At present, it is one of the areas of modern biology and it points to challenges in the medicinal field in the face of the possible regeneration of damaged cells, physical and functional integrity, the creation of thoughts in decision-making, among others that may come. to know a significant part of human existence (Dzul \& Uscanga, 2021).

Neural networks in connection with learning have made it possible to understand human behavior holistically, thanks to their nature in areas of psychology, marketing, education, and others. The teacher must know the functions of the brain, to identify in students the condition of assimilating the orientations in their mind, their personalities that are unique and related to their experience (Tacca et al., 2019).

It can be noted that learning starts from the synapse, where the environment, stimulation, and various variables that the child experiences throughout his life influence, from a young age a network of knowledge is formed that must be consolidated during the instruction process and adaptation in each school stage, being the most relevant in the first years of its existence (Gago \& Elguier, 2018). Children must have adequate nutrition, a stable family environment, health, and a well-prepared teacher and even the companions around them, these will be factors in the transmission, acquisition, and storage of knowledge. The interest in investigating this scientific issue in the classrooms of Latin America leads to creating strategies in the management of education mediated by learning based on neurodidactics, improving the quality of techniques related to teaching-learning, integrating the mind and reason, strengthening the school performance of infants (Carrillo Cusme \& Zambrano Montes).

There are differences in the learning of an adult and a child, at the beginning neuroscience research was based on the analysis of adults, the teachers' classes were focused mainly on young people, which led to the assertion of the so-called neuropsychology of the development that is responsible for experiencing the behavior of growing brains; Since the sensations and rewards are different in both parts, it is necessary to establish the ones that are adapted to apply them according to the case (Wolf, 2009). From this study arises the incompatibility between pedagogy that is responsible for studying children and adolescents and andragogy for adults, likewise, the first is responsible for instructing using methods including routine planning or organization and the second uses more independent tools according to the level of cognitive growth (Sala, 2017). Neuroscience studies are closely linked to wisdom, which has been favored with the 
interpretation that all brain processes have had, to be able to be certain that the mind is responsible for emotions, intelligence, memory, and the sensations that occur through the senses (Klimesch, 1997).

These brain functions have allowed learning to be significant in the formation of the person, especially in the first years of life, where it is evident that the stimulation of this organ can allow better learning of the child and a high IQ. All learning changes the brain, but instruction does so in an intentional, directed way, consciously taking advantage of the possibilities it provides. Man is a hybrid being of nature and culture, with plastic and autopoietic systems, which are built properly (Gallego, 2017).

Some research in Ecuador mentions that neuroscience, together with neuroeducation, is configured as a necessity for teachers, allowing the implementation of educational practices in the academic curricular system, which respond to the education of warmth, quality, efficiency, and effectiveness (Verdugo \& Campoverde, 2021).

Educational institutions qualitatively and quantitatively evaluate those involved, obtaining information regarding how they obtain inquisition interacting alone or in a team, adhere to functions such as concentration, language, construction, in addition to the contexts of mathematics, calculation, writing, and sentimental aspects; The condition for them to be carried out many times is with a multidisciplinary team that applies organized and systematized neuropsychological tests, measuring these capacities, highlighting their strengths. It is necessary for caregivers who are immersed in children's training to work in the areas of attention, affective bonds, and successful communication, knowing how a brain grows into a healthy, selfregulating organ capable of cultivating itself (Stamm, 2019). The objective of this work is to determine the contribution that neuroscience has had in initial and preparatory education based on the analysis and interpretation of the bibliographic review of several authors.

\section{Materials and Methods}

The research used a descriptive and explanatory methodology that sought to interpret, observe, describe and study the variables, it is descriptive because it allowed to analyze, summarize and detail the characteristics of neuroscience and its relationship with initial education - preparatory, through the review of the specialized literature of the different authors cited in this article, managing to obtain precise conclusions, it is historicallogical since it compared events of other times with general experiences of the evolution that neuroscience had, it is explanatory already that allowed to clarify and understand the behavior of the variables and their cause-effect relationship within the context studied for further explanation.

\section{Results and Discussions}

The human brain is quite complex, it represents a creative and renovating system that oversees functions and processes related to knowledge, thought, imagination, emotions, and other terminologies that put neurons into operation, which are connected as networks, and They react to environmental stimuli by modifying their organization and operation (Sierra \& León, 2019). Neuroscience is a discipline that interdisciplinary studies the functioning of the nervous system of the human brain, exploring neurons, learning mechanisms, other brain functions; Thanks to this science, human behavior can be understood by providing the opportunity to create and apply learning methods that allow learning in different ways considering emotions (Gómez \& Vázquez, 2018).

Anyone who spends time working with children, such as doctors, educators, psychologists, psych pedagogues, among others, know the importance of plasticity in childhood to generate a good diagnosis because the metabolism that occurs in that stage of life is more active than in adults; so that children can quickly regain brain plasticity after brain injury or damage. An injury to the left hemisphere would imply aphasia in adulthood, a child with said injured hemisphere will be able to regain speech thanks to its greater brain plasticity, the right hemisphere assuming linguistic competencies, which means that synaptic plasticity and connectivity have a greater capacity for learning and recovery in the first years of life (Reina, 2017).

Guerrero, J. A. A., Moreira, J. A. M., Zambrano, M. J. Z., Rivas, F. E. C., \& Pilligua, M. L. B. (2021). Applied neuroscience in early childhood and high school education. International Journal of Social Sciences and 
Teachers have a hard job working with students in early childhood education; Since, at this age, the development of emotional skills is essential, highlighting those that focus on cognitive and emotional selfregulation, which will play a fundamental role in the growth and development of the child (Soler et al., 2016). The role of parents in the face of neuroeducation is necessary so that they know the principles of it, thus being able to accompany and support their children during the learning process, which consists of understanding that each brain is unique and unrepeatable and changes daily with their environment, stimuli, and emotions, which will influence all their mental processes (Bueno \& Forés, 2018).

Between psychology, neurosciences, and education there is a relationship that allows the presence of neuroeducation in such a way that a significant contribution is generated in the teaching-learning processes; In addition, it brings educators closer to knowledge related to the brain, rescues the presence of other disciplines such as neuropsychology, whose central function is to study the nervous system following behavior and the mind, and finally highlights an indispensable discipline in the field of neurosciences such as neurodidactics, considering that it directs to create new methodologies in the classroom to optimize the teaching-learning processes, determining techniques, resources, and strategies that the teacher uses to awaken the student's interest from motivation, generating knowledge (Gallego, 2019).

In learning there is an essential component that is the capacities of emotional intelligence, disseminated in 1983, which refers to multiple intelligences, these arise after 16 years, noting that throughout history it has generated debate on the part of scientists, concluding that there is no universal concept about it. There are several theories related to this issue, which has caused some authors to establish various categories (Cox, 2005; Cubukcu, 2009). Theories of intelligence can be classified as implicit and explicit; the implicit ones do not have scientific evidence to support them and the explicit ones are the result of a research process that is classified into four large groups: psychometric, biological, developmental, and multiple intelligences (Ruiz \& García, 2019). The types of intelligence characterize each person by their capacities and talents. Table 1 shows the types of multiple intelligences and their description.

Table 1

Types of multiple intelligences

\begin{tabular}{|c|c|}
\hline Types of Intelligence & Description \\
\hline Musical & $\begin{array}{l}\text { Ability to interpret sounds, the person has a fine ear for tones, } \\
\text { doorbells, and rhythms. They can learn or communicate with } \\
\text { musical forms. }\end{array}$ \\
\hline Body - Kinesthetic & $\begin{array}{l}\text { The ability to coordinate mind and body can be expressed } \\
\text { through body movements. }\end{array}$ \\
\hline Linguistics & $\begin{array}{l}\text { Ability to acquire one or more languages with ease and } \\
\text { express it in all their expressions. }\end{array}$ \\
\hline Logical-Mathematical & $\begin{array}{l}\text { Ability to quantify things, make hypotheses, and give quick } \\
\text { solutions to problems. }\end{array}$ \\
\hline Spatial & $\begin{array}{l}\text { Ability to visualize the world in 3D, transform the way we see } \\
\text { things. }\end{array}$ \\
\hline Interpersonal & $\begin{array}{l}\text { Ability to perceive feelings and motivations of others, through } \\
\text { social interaction. }\end{array}$ \\
\hline Intrapersonal & Ability to understand oneself, know oneself, and self-value. \\
\hline Naturalist & $\begin{array}{l}\text { Ability to understand things in life, read, and investigate the } \\
\text { elements of nature. }\end{array}$ \\
\hline
\end{tabular}

Source: (Saquicela, 2019)

In children, learning will occur with surprising speed, especially at an early age, where experiences are already shaping the brain and designing that neural architecture that will influence the next contexts and spaces in those who develop, report that mirror neurons are the ones that make a great contribution to learning because they allow us to empathize with the emotional lives and the intentional states of others, thus guiding our lives in the communicative and cultural aspects; thus, the help and support of social intelligence is activated by gestures helping to read the intentions of students and predict behavior (Saquicela, 2019). At the 
initial level there must be an adequate stimulation of learning that significantly strengthens skills, competencies, adaptation, and other brain functions, since it has been scientifically proven that those children who have been stimulated at an early age show greater brain development given that neuronal plasticity and synapse in early ages occur with greater speed (Santi-León, 2019).

The process of synaptic connection and brain plasticity is exuberant because the brain does not add as many cells after birth unlike the other organs of the body, but if it grows the extensions of these cells create an incredible communication network (Dodt \& Zieglgänsberger, 1990), this growth of The synapse is allowing in parallel that many sensory, cognitive, social, motor and emotional skills are activated that will allow children to be part of the world that surrounds them, grow and develop, it is precisely in this space where education from the participation of the educator and family will allow their integral development (Bodero, 2017; Volkova \& Fedorinova, 2020). Neurosciences have made a notable contribution to initial education because it has made it possible to understand how the child's brain learns in various ways, the learning difficulties it can present, the importance of stimuli, emotions, and the environment in which it operates (Stein et al., 1988); know the mirror neurons related to imitation and interaction, as well as the importance of physical activity and sleep in the early years; It is necessary to remember that much remains to be investigated in terms of brain development and the quality in which it learns (Gago \& Elgier, 2018; Hidayat \& Budiatma, 2018). The fundamental principles of neuroscience that are directly related to learning are shown in Figure 1, as contributions that neuroeducation has in the educational environment.
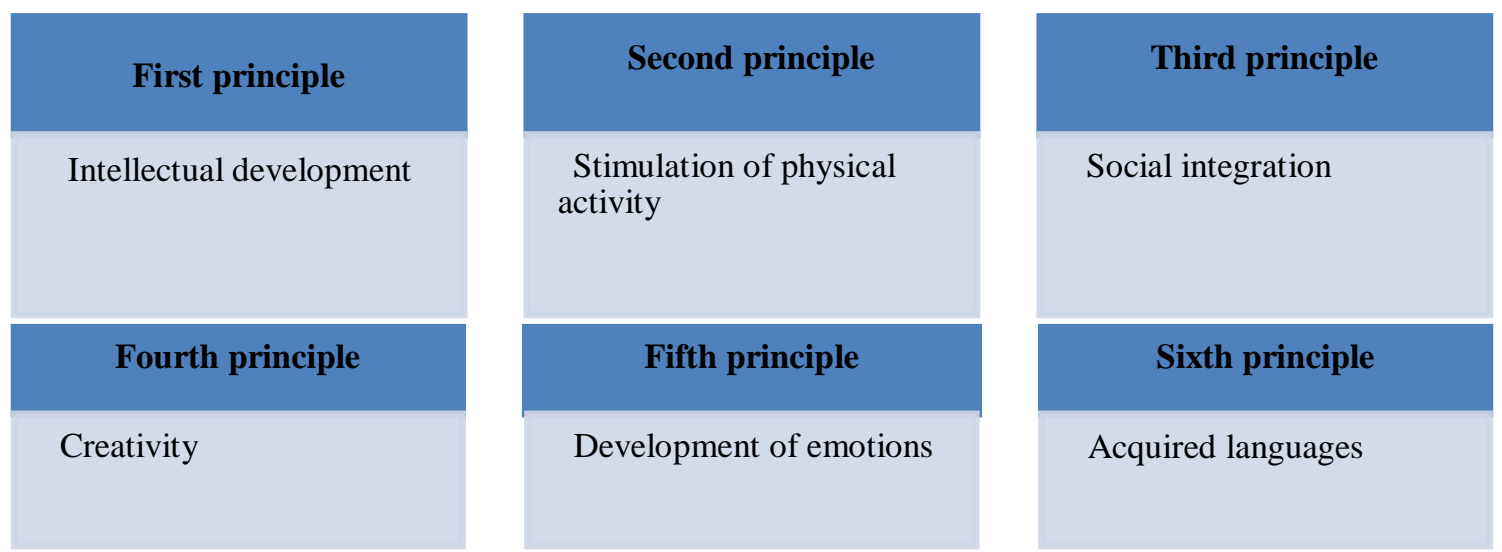

Figure 1. Fundamental principles of neuroscience Source: (Largada \& Giménez, 2018)

These principles are part of a general structure of the capacities that can be developed with greater success from an early age, applying strategies such as active methodologies and soft skills that the teacher must know to identify important attitudes and skills in children (Murray, 1996; Swanson \& Smalheiser, 1997). Despite the relevance of neurosciences (neuroeducation and neurodidactics), some problems affect the pedagogical practices of teachers that do not allow the development of learning in pre-school children; These deficiencies are related to inadequate class planning in their methodological strategies (Derossis et al., 1998), teachers' ignorance about brain development, stimulation and the incorrect application of didactics in the classroom using strategies that have no scientific support, which can guide students not correctly stimulating children (Gallego, 2019). The role of the teacher in the learning of initial-level children is essential and that implies that the relevance of applying active methodologies and innovative tools that enhance experiential, experiential, meaningful, and comprehensive learning is recognized (Araya-Pizarro \& Espinoza Pastén).

Despite the studies carried out, various functions of the brain remain an attractive enigma to the curiosity of scientists, a topic that has been clear so far is that the study of this organ has given rise to neurosciences, which are associated with Education allows us to understand the processes of applied learning in students of initial and preparatory education, as well as guides teachers to improve pedagogical practice (Sharp \& Brouwer, 1997). The topic addressed in the analysis of specialized literature showed

Guerrero, J. A. A., Moreira, J. A. M., Zambrano, M. J. Z., Rivas, F. E. C., \& Pilligua, M. L. B. (2021). Applied neuroscience in early childhood and high school education. International Journal of Social Sciences and Humanities, 5(3), 223-231. https://doi.org/10.53730/ijssh.v5n3.2027 
that a child's brain learns faster than an adult's. This is the reason why it is important to stimulate children considering the contribution offered by neuroeducation and neurodidactics, contributing to the development of brain functions of those who in the future will be young people with a high IQ and critical thinking.

\section{Conclusion}

It was determined that the brain of a child learns faster than the adult, showing that neurosciences influence the teaching-learning process in pre-school and high school students of the Mathius Quintanilla Sierra Educational Unit. This can be accomplished with the support of teachers, parents, fostering researchreflection spaces that allow them to understand the variety of sciences that are studied.

Acknowledgments

We are grateful to two anonymous reviewers for their valuable comments on the earlier version of this paper. 


\section{References}

Araya-Pizarro, SC, \& Espinoza Pastén, L. (2020). Contributions from the neurosciences for the understanding of learning processes in educational contexts. Purposes and Representations , 8 (1).

Bodero, C. (2017). Neuroscience in early childhood. Notes of social sciences, 7(01), 6-10.

Bueno, D, \& Forés, A. (2018). 5 principles of neuroeducation that the family should know and put into practice. Ibero-American Journal of Education, 78(1), 13-25.

Carrillo Cusme, Z. L., \& Zambrano Montes, L. C. (2021). Nuerodidactic strategies applied by teachers at the Ángel Arteaga school of Santa Ana. Revista San Gregorio, 1(46), 144-157.

Cox, M. T. (2005). Metacognition in computation: A selected research review. Artificial intelligence, 169(2), 104-141. https://doi.org/10.1016/j.sbspro.2011.04.364

Cubukcu, F. (2009). Metacognition in the classroom. Procedia-Social and Behavioral Sciences, 1(1), 559-563. https://doi.org/10.1016/j.sbspro.2009.01.101

Dehaene, S. (2019). How do we learn? The four pillars with which education can enhance the talents of our brain. Argentina: Twenty-first Century.

Derossis, A. M., Fried, G. M., Sigman, H. H., Barkun, J. S., \& Meakins, J. L. (1998). Development of a model for training and evaluation of laparoscopic skills. The American journal of surgery, 175(6), 482-487. https://doi.org/10.1016/S0002-9610(98)00080-4

Dodt, H. U., \& Zieglgänsberger, W. (1990). Visualizing unstained neurons in living brain slices by infrared DICvideomicroscopy. Brain research, 537(1-2), 333-336. https://doi.org/10.1016/0006-8993(90)90380-T

Dzul, E. \& Uscanga, I. (2021). The brain in time - a journey of neuroscience. Institute of Neuroethology, Universidad Veracruzana.

Gago, L., \& Elguier, Á. (2018). Building bridges between neuroscience and education. Contributions, limits and future paths in the educational field. Psychogente, 21(40), 476-494.

Gallego, I. (2017). Neuroscience in the educational field. International Journal of Support for Inclusion, Speech Therapy, Society and Multiculturalism, 3(1), 118-135,

Gallego, M. (2019). Contributions of neuroeducation to the initial education of children between 0 and 2 years of age. A socio-critical approach to pedagogical practices in the Ludotekas of Medellín. (Postgraduate thesis). Universidad de Antioquia UDEA digital library.

Gómez, M., \& Vázquez, E. (2018). Contributions of Neurosciences to education. TEPEXI: Scientific Bulletin of the Tepeji del Río High School, 5(10), 1-6.

Hidayat, R., \& Budiatma, J. (2018). Education and job training on employee performance. International Journal of Social Sciences and Humanities, 2(1), 171-181. https://doi.org/10.29332/ijssh.v2n1.140

Klimesch, W. (1997). EEG-alpha rhythms and memory processes. International Journal of psychophysiology, 26(1-3), 319-340. https://doi.org/10.1016/S0167-8760(97)00773-3

Lengthened, D., Giménez, J. (2018). Educational principles and neuroeducation: a foundation from science. EDETANIA, 55(1), 165-171.

Murray, E. A. (1996). What have ablation studies told us about the neural substrates of stimulus memory?. In Seminars in Neuroscience (Vol. 8, No. 1, pp. 13-22). Academic Press. https://doi.org/10.1006/smns.1996.0003

Palacios, L. (2021). Paul Broca and his Contributions to Neuroscience. Medicine Magazine, 43(3), 445-449.

Reina, A. (2017). Neuroscience-based learning strategies for the development of oral expression in infants 1 to 2 years of age. Virtual Magazine "Perspectives In Early Childhood, 4(1), 3-4.

Ruiz, C., \& García, L.M., (2019). Qualifying mention in emotional intelligence of the Infant Education Degree. $A$ Open School, 22(1), 3-13.

Sala, A. 2017. Differences in musical learning between a child and an adult. Step Notes, 14(1), 1-16.

Santi-León, F. (2019). Education: The importance of child development and initial education in a country where they are not compulsory. UMEI Science Magazine, 12(30), 143-159.

Saquicela, C. (2019). Neurodidactics as a pedagogical tool within the praxis of General Basic Elementary Education teachers at Colegio San Gabriel (Bachelor's thesis). Pontifical Catholic University of Ecuador, Ecuador.

Sharp, S. A., \& Brouwer, B. J. (1997). Isokinetic strength training of the hemiparetic knee: effects on function and spasticity. Archives of physical medicine and rehabilitation, 78(11), 1231-1236. https://doi.org/10.1016/S0003-9993(97)90337-3

Guerrero, J. A. A., Moreira, J. A. M., Zambrano, M. J. Z., Rivas, F. E. C., \& Pilligua, M. L. B. (2021). Applied neuroscience in early childhood and high school education. International Journal of Social Sciences and 
Sierra, E., \& León, M. (2019). Brain Plasticity, a neural reality. Journal of Medical Sciences of Pinar del Río, 23(4), 599-609.

Soler, J., Aparicio, L., Díaz, O., Escolano, E., \& Rodríguez, A. (2016). Emotional intelligence and well-being II. Editorial San Jorge.

Stamm, J. (2019). Infant Neurosciences: Mind Development and Brain Power Ages 0-6. Madrid: Narcea SA.

Stein, B. E., Huneycutt, W. S., \& Meredith, M. A. (1988). Neurons and behavior: the same rules of multisensory integration apply. Brain research, 448(2), 355-358. https://doi.org/10.1016/0006-8993(88)91276-0

Swanson, D. R., \& Smalheiser, N. R. (1997). An interactive system for finding complementary literatures: a stimulus to scientific discovery. Artificial intelligence, 91(2), 183-203. https://doi.org/10.1016/S00043702(97)00008-8

Tacca, D., Tacca, A., \& Alava, A. (2019). Neurodidactic strategies, satisfaction and academic performance in university students. Educational Research Notebooks, 10(2), 15-32.

Verdugo, C., \& Campoverde, A. (2021). Educational neuroscience: A proposal regarding the need for quality education in Ecuador. Science Mastery, 7(1), 239-260.

Volkova, N., \& Fedorinova, Z. (2020). Pedagogical activity formation in Russian students training. International Journal of Social Sciences and Humanities, 4(2), 77-84. https://doi.org/10.29332/ijssh.v4n2.410

Wolf, O. T. (2009). Stress and memory in humans: twelve years of progress? Brain research, 1293, 142-154. https://doi.org/10.1016/j.brainres.2009.04.013 


\section{Biography of Authors}

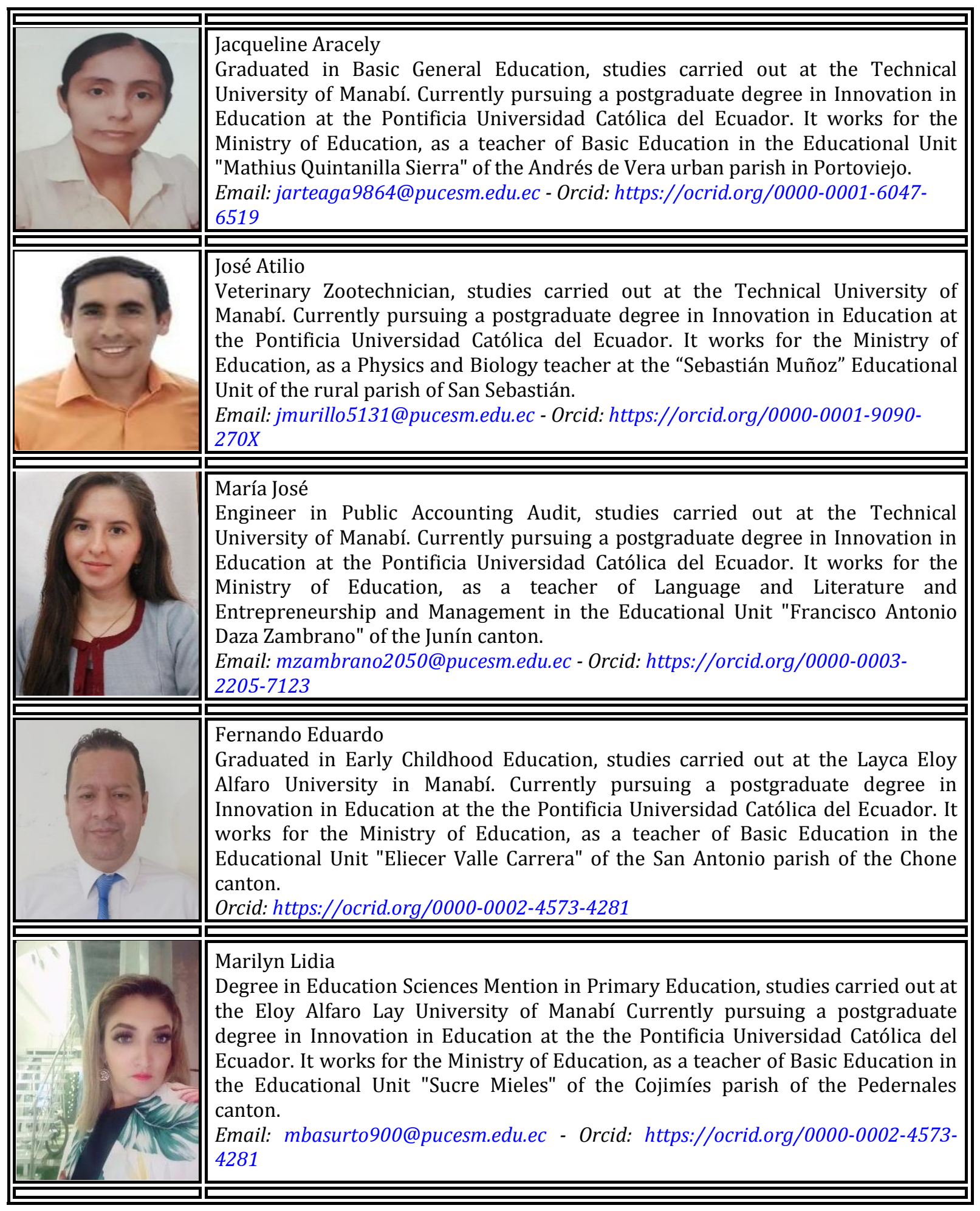

Guerrero, J. A. A., Moreira, J. A. M., Zambrano, M. J. Z., Rivas, F. E. C., \& Pilligua, M. L. B. (2021). Applied neuroscience in early childhood and high school education. International Journal of Social Sciences and Humanities, 5(3), 223-231. https://doi.org/10.53730/ijssh.v5n3.2027 